GEOLOGICAL SURVEY

FLOODFLOW ANALYSIS OF NINEMILE CREEK, ONONDAGA COUNTY, NEW YORK

By Richard Lumia and Bernard Dunn

U.S. GEOLOGICAL SURVEY

Open-File Report 78-85

Prepared in cooperation with

New York State Department of Transportation

Albany, New York

January 1978 
Conversion factors and abbreviations.....................111

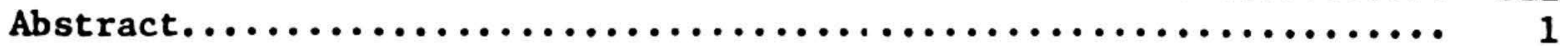

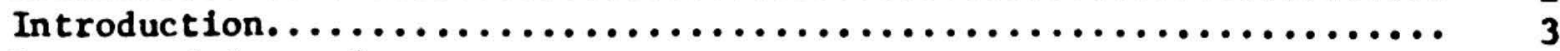

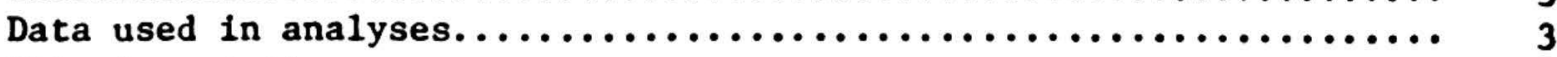

Site description................................... 4

Magnitude and frequency of floods........................ 4

Hydraulic analysis................................. 5

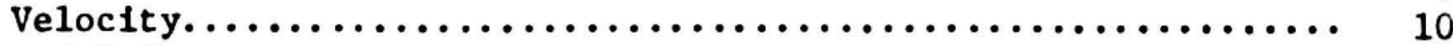

Selected References.................................. 10

\section{ILLUSTRATIONS}

Figure 1. Map of study reach, Camillus to Amboy, N.Y., showing location of major features...................... 2

2-4. Flood profiles of study reach, Camillus to Amboy, N.Y., under four different channel conditions:

2.--Flood profiles for 50 -year flood............... 6

3.--Flood profiles for 100 -year flood,............. 7

4.--Flood profiles for flood of September 26, 1975...... 8

\section{TABLES}

Table 1. Flood freçuency and discharge, Ninemile Creek at

Camillus, N.Y

\section{CONVERSION FACTORS AND ABBREVIATIONS}

Multiply English units

feet $(f t)$

miles (mi)

square miles $\left(\mathrm{mi}^{2}\right)$

feet per second ( $\mathrm{ft} / \mathrm{s}$ )

cubic feet per second $\left(\mathrm{ft}^{3} / \mathrm{s}\right)$
By

.3048

1.609

2.590

.3048

.02832
To obtain metric units meters (m)

kilometers $(\mathrm{km})$

square kilometers $\left(\mathrm{km}^{2}\right)$ meters per second $(\mathrm{m} / \mathrm{s})$

cubic meters per second 


\title{
FLOODFLOW ANALYSIS OF NINEMILE CREEK, \\ ONONDAGA COUNTY, NEW YORK
}

By

Richard Lumia and Bernard Dunn

\begin{abstract}
A flood-stage and discharge analysis was made for a 3.61-mile reach of Ninemile Creek between Amboy and Camillus. Water-surface profiles were developed for 50-year, 100-year, and September 26, 1975 flood discharges at Camillus for four different channel conditions: (1) with four culverts at Camillus bypass and a bridge at County Road 36 (present conditions); (2) with only the culverts removed; (3) with only County Road 36 bridge removed; and (4) with the culverts and County Road 36 bridge removed (preconstruction conditions). The 50- and 100-year flood discharges at the Camillus gaging station were determined to be 4,700 and 5,500 cubic feet per second, respectively, and the September 1975 flood discharge was measured to be 2,120 cubic feet per second. If the four culverts are removed, peak water-surface elevations at the gaging station in Camillus during the 50- and 100-year flood would be decreased by 0.7 and 0.3 foot, respectively, relative to those calculated for present conditions. If only County Road 36 bridge is removed, water-surface elevations during the 50- and 100-year flood would be decreased by 0.2 and 0.3 foot, respectively. If both structures are removed, water-surface elevations during the 50- and 100-year floods would be decreased by 0.8 and 0.6 foot, respectively. None of the channel variations would have altered the water-surface elevation at the gage using the September 1975 flood discharge.
\end{abstract}




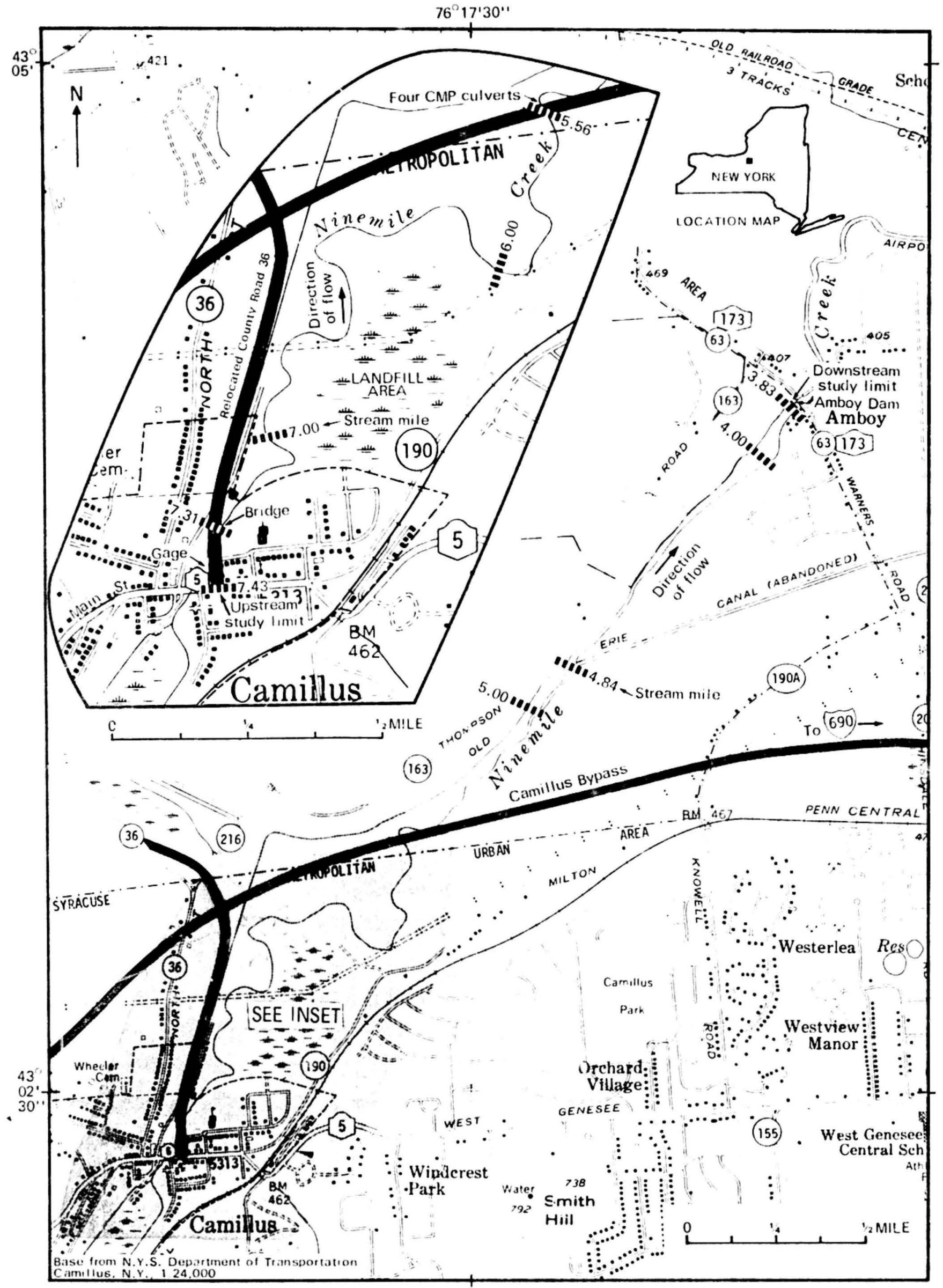

Figure 1.--Location and main features of study reach, Ninemile Creek, Amboy to Camillus, N.Y. 


\section{INTRODUCTION}

Bridge construction and local concern about recent flooding in the town of Camillus provided impetus for a hydraulic analysis of the 50year and 100-year f..oods and of the peak discharge of the September 1975 flood on a 3.61-mile reach of Ninemile Creek between Amboy and Camillus, Onondaga County, New York (fig. 1). The September 1975 flood analysis did not include certain adverse influences within the reach, namely a temporary construction haul road, incomplete bridge construction, logjams or other debris in the channel, etc., at the time of the flood. The 50- and 100-year flood analyses did not consider the logjams or debris. These conditions could raise water levels higher than those determined in this analysis. Water-surface profiles were developed for each of the three floods with the following variations:

(1) with four culverts at Camillus bypass and a bridge at County Road 36 (present conditions),

(2) with four corrugated-metal pipe (CMP) culverts at Camillus bypass removed,

(3) with County Road 36 bridge removed, and

(4) the four culverts at Camillus bypass and relocated County Road 36 bridge removed (preconstruction conditions).

The study was done by the U.S. Geological Survey in cooperation with the New York State Department of Transportation.

\section{DATA USED IN ANALYSIS}

Information and records on which the flood analyses were made include:

(1) cross-sectional data for the study reach (provided by the New York State Department of Transportation and the U.S. Geological Survey);

(2) plan drawings of new structures (furnished by the New York State Department of Transportation);

(3) peak-discharge data (collected by the U.S. Geological Survey at gaging station 04240200 in Camillus).

Records and computations supporting the interpretations in this report are available for inspection at the U.S. Geological Survey office in Albany, New York. Computations are based on channel and flood-plain data

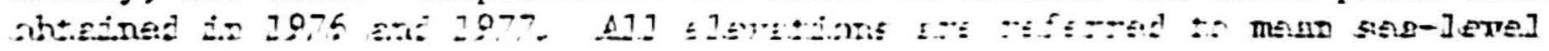
datum of 1929. 


\section{SITE DESCRIPTION}

Ninemile Creek has a narrow basin with a drainage area of $84.3 \mathrm{mi}^{2}$ at Camillus and $96.0 \mathrm{mi}^{2}$ at Amboy (fig. 1). It begins at the outlet (dam) of Otisco Lake, $6.0 \mathrm{mi}$ upstream (southwest) of Camillus, which regulates the flow from $42.5 \mathrm{mi}^{2}$. Water from Otisco Lake is diverted to the city of Syracuse water supply. At times of extreme flooding, Otisco Lake spills uncontrolled into Ninemile Creek. The mouth of Ninemile Creek is $7.3 \mathrm{mi}$ below Camillus, on the southwest shore of Onondaga Lake. Points are hereafter referred to in stream miles above the mouth.

Five structures within the study reach (fig. 1) control flow during medium and high stages:

(1) a dam in Amboy at mile 3.83;

(2) a viaduct of old Erie Canal at mile 4.84;

(3) a four-lane divided highway (referred to as Camillus bypass) under construction, extending west from U.S. Highway 690, north of State Highway 5, with four CMP culverts beneath it at mile 5.56;

(4) a newly constructed bridge at mile 7.31, just downstream from State Highway 5 (Main street) and the gaging station, at relocated County Road 36;

(5) a bridge at mile 7.43 at State Highway 5 (Main Street).

The Town of Camillus operated a sanitary landfill on the right flood plain between stream mile 6.0 and 7.0. This encroachment onto the floodplain was included in the analysis. The sanitary landfill is now closed.

Substantial amounts of debris are evident along the flood plain throughout the study reach. During the September 26, 1975 flood, logjams were reported at stream miles 5.03 and 5.73 .

\section{MAGNITUDE AND FREQUENCY OF FLOODS}

Records of flood stages and discharges on Ninemile Creek have been collected since 1959 by the U.S. Geological Survey at gaging station $04240200,150 \mathrm{ft}$ downstream from State Highway 5 (Main Street) bridge in Camillus. Records for each year are published in the annual U.S. Geological Survey report, "Water Resources Data for New York."

A log-Pearson type-III analysis was made of annual peak discharges obtained from the gaging station at Camillus. Flood-frequency data resulting from that analysis are shown in table 1. 
Table 1.--Flood-magnitude data, Ninemile Creek at Camillus, N.Y.

\begin{tabular}{ccc}
\hline & Frequency & \\
$\begin{array}{c}\text { Recurrence } \\
\text { Interval } \\
\text { (years) }\end{array}$ & $\begin{array}{c}\text { Exceedance Probability } \\
\text { (percent) }\end{array}$ & $\begin{array}{c}\text { Discharge } \\
\left(\mathrm{ft}^{3} / \mathrm{s}\right)\end{array}$ \\
\hline 2 & 50 & \\
5 & 20 & 1,350 \\
10 & 10 & 2,220 \\
25 & 4 & 2,890 \\
50 & 2 & 3,800 \\
100 & 1 & 4,700 \\
& & 5,500 \\
\hline
\end{tabular}

Flood frequency (or recurrence interval) is the average number of years within which a given flood magnitude (discharge) will be equaled or exceeded once. The reciprocal of this value, or exceedance probability, is the percent chance that a flood of given magnitude will be equaled or exceeded in 1 year (Beard, 1962).

The 50- and 100-year flood discharges of $4,700 \mathrm{ft}^{3} / \mathrm{s}$ and $5,500 \mathrm{ft}^{3} / \mathrm{s}$, respectively, at the gaging station in Camillus were used for the study. Discharge measured at the gaging station during the September 1975 flood was $2,120 \mathrm{ft}^{3} / \mathrm{s}$. The 50- and 100-year flood discharges at the Amboy Dam (mile 3.83) were determined from a regional relationship (adopted from the U.S. Army Corps of Engineers, Buffalo District) to be $5,800 \mathrm{ft}^{3} / \mathrm{s}$ and $6,900 \mathrm{ft}^{3} / \mathrm{s}$, respectively. Discharge at the dam during the September 1975 flood is estimated to have been $2,620 \mathrm{ft}^{3} / \mathrm{s}$. Discharges were adjusted at applicable points within the study reach, such as tributaries, abandoned Erie Canal, and so forth.

Discharges derived for the 50- and 100-year floods at the gage were compared with those of the U.S. Army Corps of Engineers, Buffalo District. The methods used by both agencies are in accordance with guidelines set forth by the U.S. Water Resources Council (1976).

\section{HYDRAULIC ANALYSIS}

Water-surface profiles of the entire study reach were developed for the 50-year, 100-year, and the September 26, 1975 flood discharges for each of the conditions listed previously (p. 3). These profiles were computed by the standard step-backwater method (Chow, 1959 and Shearman, 1976) and flow-through-culvert method (Bodhaine, 1968) and are given in figures 2-4. Starting elevations for each profile were computed using critical depth for each discharge at Amboy Dam. 


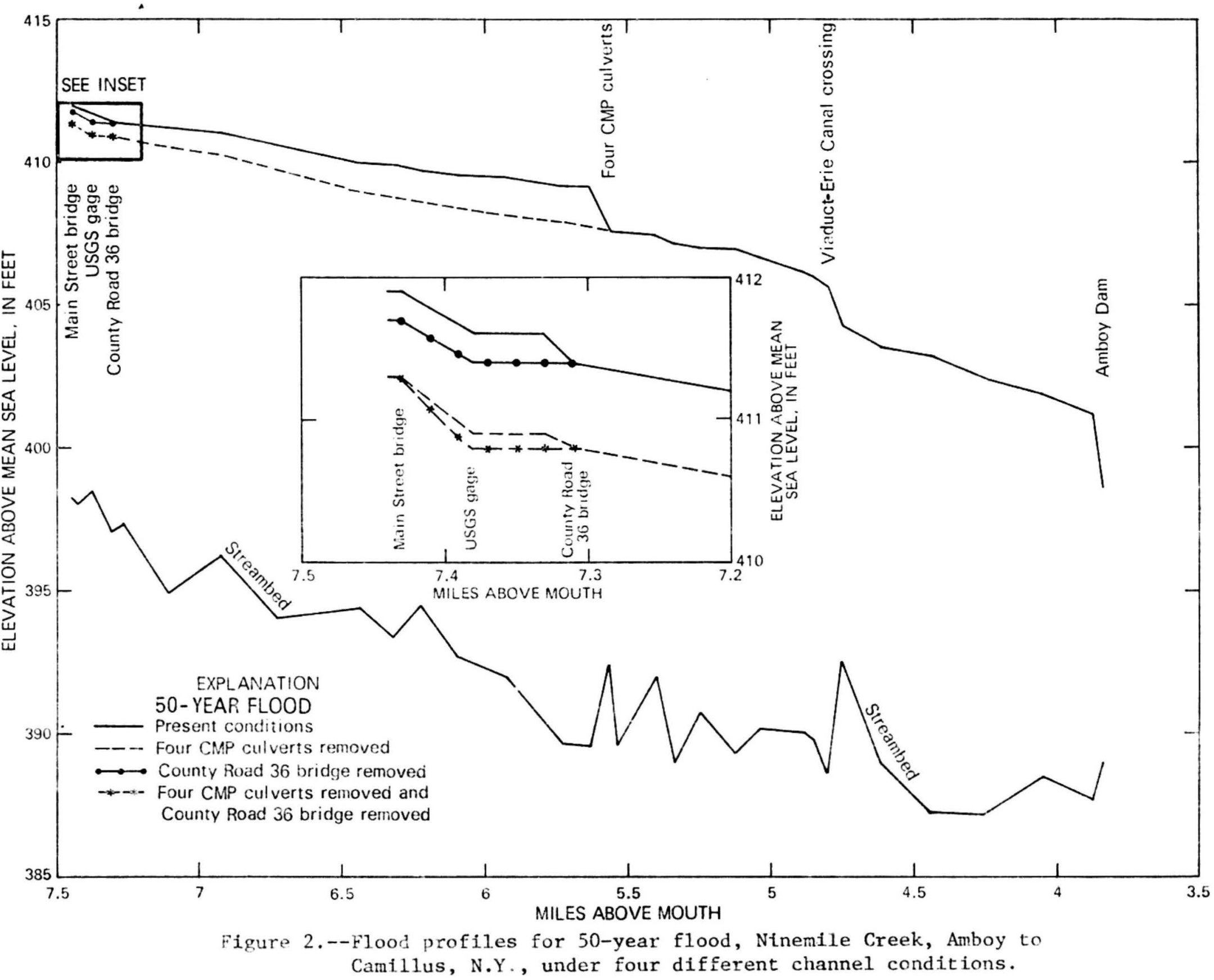




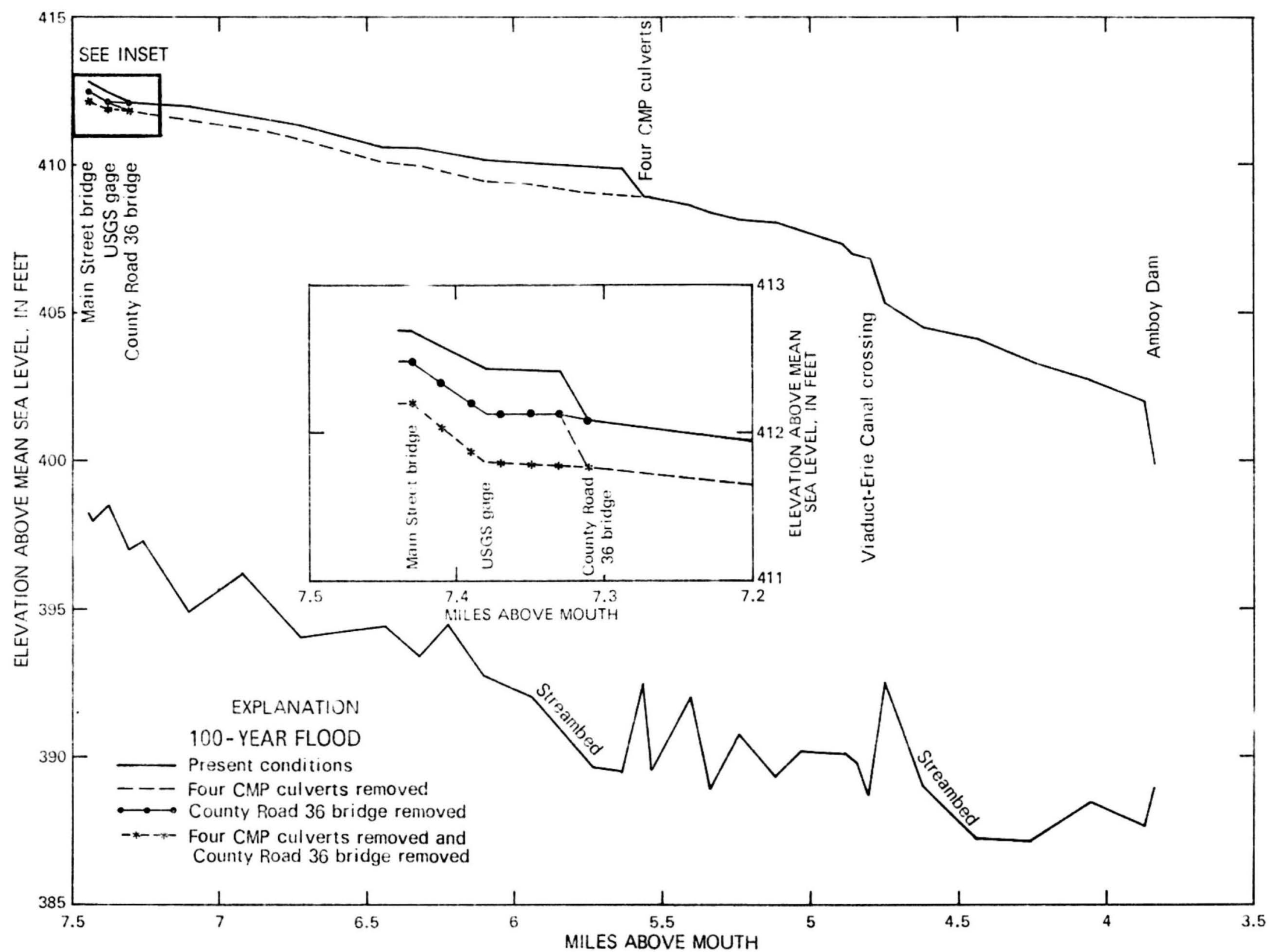

Figure 3.--Flood profiles for 100-year flood, Ninemile Creek, Amboy to Camillus, N.Y., under four different channel conditions. 


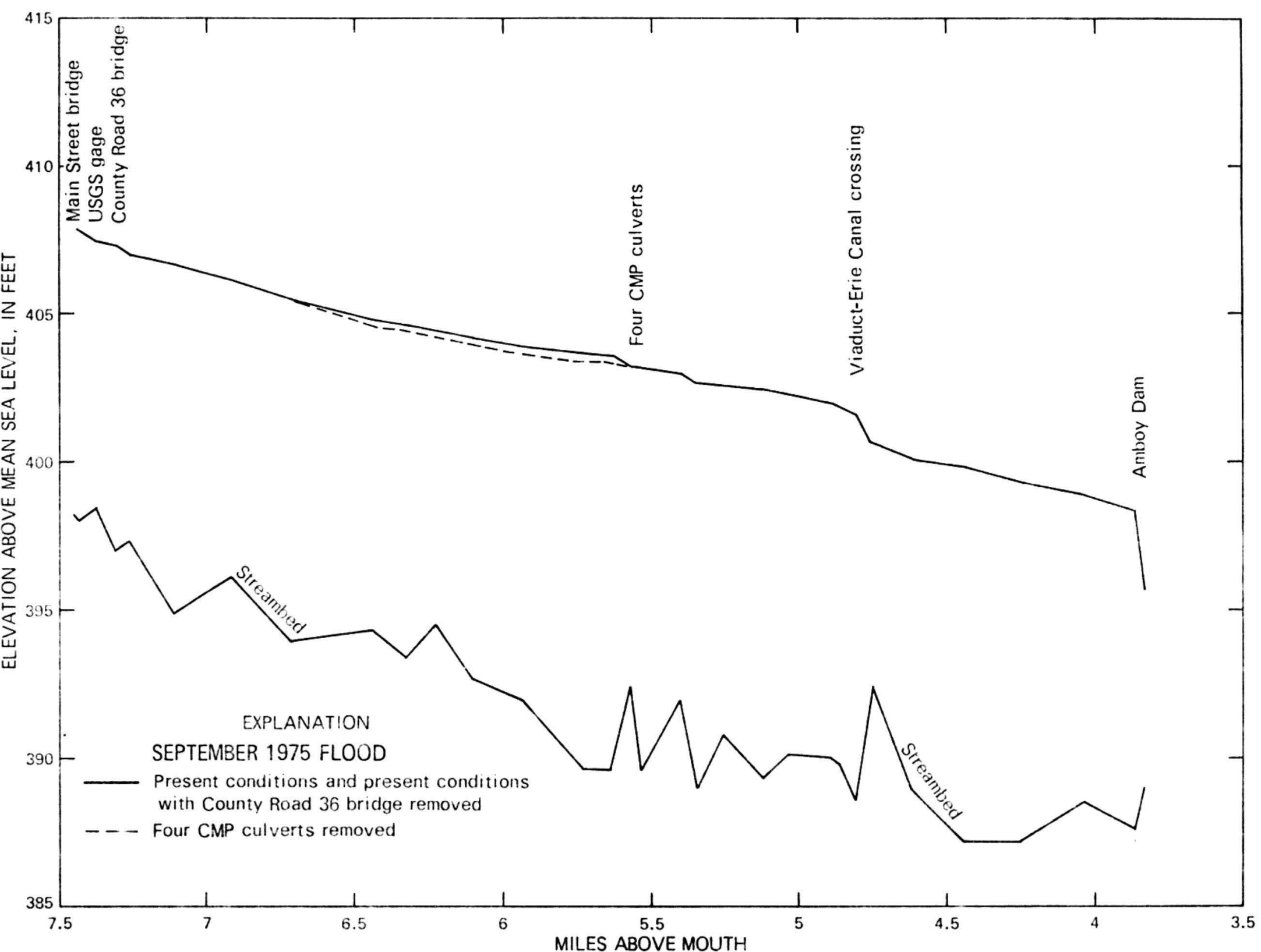

Figure 4.--Flood profiles for flood of September 26, 1975, Ninemile Creek, Amboy to Camillus, N.Y., under four different channel condicions. 
Step-backwater computations for the September 26, 1975 flood under present channel conditions (condition 1, p. 3) indicate a water-surface elevation of $407.4 \mathrm{ft}$ at the gaging station in Camillus (mile 7.38), which is comparable to the peak stage of $409.4 \mathrm{ft}$ recorded during that flood. The 2.0-ft difference is attributable to the presence of debris, logjams, and other obstructions in the channel at the time of the flood.

The water-surface profiles developed for condition 2 (with the four culverts at Camillus Bypass removed and with the County Road 36 bridge remaining) indicate a respective $0.7-\mathrm{ft}$ and $0.3-\mathrm{ft}$ decrease in watersurface elevations for the 50- and 100-year floods at the gaging station relative to those calculated for present conditions. This condition would cause no change in water-surface elevation at the gage for the September 1975 flood discharge.

Computation of water-surface profiles for condition 3 (with County Road 36 bridge removed and the four culverts at Camillus Bypass remaining) show a $0.2-\mathrm{ft}$ and $0.3-\mathrm{ft}$ decrease in water-sur...e elevation at the gage for the 50- and 100-year floods, respectively, relative to those calculated for present conditions. Again, condition 3 would cause no change in watersurface elevation at the gaging station using the September 1975 flood discharge.

Computation of water-surface profiles for condition 4 (preconstruction conditions), without the culverts at the Camillus Bypass and without the County Road 36 bridge), indicate a decrease in water-surface elevation of $0.8 \mathrm{ft}$ and $0.6 \mathrm{ft}$ for the 50- and 100-year floods, respectively, at the gaging station relative to those calculated for present conditions. Again, under condition 4, profiles for the September 26, 1975 flood discharge indicate no change in water-surface elevation at the gage. However, the effects of the haul road, logjams, and debris in the channel during the September 1975 flood were not included in the analysis.

Also determined in this study was the amount of water that would flow over the road embankment at the four culverts at Camillus Bypass and at County Road 36 bridge during the selected floods. At the Camillus bypass during the 50 -year flood, $2,350 \mathrm{ft}^{3} / \mathrm{s}$ would overflow the culverts and $2,850 \mathrm{ft}^{3} / \mathrm{s}$ would flow through them. During the 100-year flood, $3,950 \mathrm{ft}^{3} / \mathrm{s}$ would overflow the culverts and $2,200 \mathrm{ft}^{3} / \mathrm{s}$ would flow through them. At County Road 36 bridge during the 50 -year flood, $1,180 \mathrm{ft}^{3} / \mathrm{s}$ would flow over the road and $3,520 \mathrm{ft}^{3} / \mathrm{s}$ through the bridge; and during the 100 -year flood, $1,770 \mathrm{ft}^{3} / \mathrm{s}$ would flow over the road and $3,730 \mathrm{ft}^{3} / \mathrm{s}$ through the bridge. At the September 1.975 flood discharge, no road overflow is indicated at either structure. Again, the previously mentioned adverse channel conditions were not considered in these analyses. 


\section{Velocity}

Average velocities in the main channel throughout the study reach under present conditions during the 50-year flood were determined to range from $1.9 \mathrm{ft} / \mathrm{s}$ at mile 7.10 to $9.3 \mathrm{ft} / \mathrm{s}$ at mile 4.74 . During the 100 -year flood, they would range from $2.0 \mathrm{ft} / \mathrm{s}$ to $9.9 \mathrm{ft} / \mathrm{s}$. At the September 26, $1975 \mathrm{flood}$ discharge, the range would be $\mathrm{from} 1.6 \mathrm{ft} / \mathrm{s}$ to $7.3 \mathrm{ft} / \mathrm{s}$.

Velocities through the four culverts at the Camillus bypass were computed to be $5.8 \mathrm{ft} / \mathrm{s}, 4.4 \mathrm{ft} / \mathrm{s}$, and $3.6 \mathrm{ft} / \mathrm{s}$ for the 50-year, 100-year, and September, 1975 floods, respectively. Velocities at C inty Road 36 bridge were determined to be $5.3 \mathrm{ft} / \mathrm{s}, 5.6 \mathrm{ft} / \mathrm{s}$, and $4.4 \mathrm{ft} / \mathrm{s}$ for the j0-year, 100-year, and September, 1475 floods, respectively.

\section{SELECTED REFERENCES}

American Iron and Steel Institute, 1971, Handbook of steel drainage and highway construction products: New York, Am. Iron and Steel Inst., $348 \mathrm{p}$.

Beard, Leo R., 1962, Statitistical methods in hydrology: Sacramento, Calif., U.S. Army Corps of Engineers, 62 p.

Bodhaine, G. L., 1968, Measurement of peak discharge at culverts by indirect method: U.S. Geol. Survey Techniques Water-Resources Inv., book 3, chap. A3, 60 p.

Chow, Ven Te, 1959, Open-channel hydraulics: New York, McGraw-Hill Book Co., Inc., 680 p.

Shearman, James 0., 1976, Computer applications for step-backwater and floodway analysis: U.S. Geol. Survey Open-File Rept. 76-499, 103 p.

U.S. Geological Survey, Water-Resources data for New York: U.S. Geol. Survey open-file rept. [published annually].

U.S. Water Resources Council, 1976, Guidelines for determining flood flow frequenc": Washington, D.C., U.S. Water Resources Council Hydrology Committee, Bull. 1?, 25 p. 